Asian-Australasian Journal of Food Safety and Security

ISSN 2523-1073 (Print) 2523-2983 (Online)

www.ebupress.com/journal/aajfss

\title{
Article \\ Isolation and identification of bacteria in different street vended foods collected from selected areas of Bangladesh
}

\author{
Torun Kumar Paul ${ }^{1 *}$, Snigdha Rani Roy ${ }^{2}$, Pankaz Roy Sarkar $^{3}$, MoniruzzamanTarafder $^{4}$ and Tapu Kumar Saha ${ }^{5}$ \\ ${ }^{1}$ Department of Pharmacology, Bangladesh Agricultural University, Mymensingh-2202, Bangladesh \\ ${ }^{2}$ Bachelor of Dental Surgery, Rangpur Dental College, Rangpur, Bangladesh \\ ${ }^{3}$ DVM, Patuakhali Science \& Technology University, Patuakhali, Bangladesh \\ ${ }^{4}$ Office of the Deputy Director Livestock Medicine Store, Department of Livestock Services, Bangladesh \\ ${ }^{5}$ Veterinary Surgeon, Department of Livestock Services, Bangladesh
}

${ }^{*}$ Corresponding author: Torun Kumar Paul, Department of Pharmacology, Bangladesh Agricultural University, Mymensingh-2202, Bangladesh. E-mail: tarundvm14@gmail.com

Received: 01 November 2018/Accepted: 21 November 2018/ Published: 29 November 2018

\begin{abstract}
Street food vending has become an important public health issue and a great concern to everybody. This is due to widespread food borne diseases, due to the mushrooming of wayside food vendors who lack an adequate understanding of the basic food safety issues. Major sources contributing to microbial contamination are the place of preparation, utensils for cooking and serving, raw materials, time and temperature abuse of cooked foods and the personal hygiene of vendors. The objective of the study was to explore the microbiological quality of different street food; Chotpoti, Chanachur, Amra (Spondias mombin) and Jolpai (Elaeocarpus serratus (Veralu / Ceylon Olive) sold by various street vendor at Khulna city, Bangladesh. A total of 20 samples were collected randomly from street vendors and tested for the presence of bacteria following standard microbiological method used for isolation, enumaration and identification of bacreria. All the examined samples were contaminated by various types of bacteria. The total viable count (TVC) in different street food samples was ranged from 9.6 x $10 \mathrm{CFU} / \mathrm{g}$ to $5.9 \times 10 \mathrm{CFU} / \mathrm{g}$. Among samples Escherichia coli 8(40\%), Staphylococcus spp. 5(25\%), Klebsiella spp. 4(20\%), Salmonella spp. 1(5\%) and Shigella spp. 2 (10\%) were isolated. Escherichia coli were found highest 3(50\%) Jolpai samples, then another organisms Staphylococcus spp. was found highest 2(50\%) in Chotpoti and then Klebsiella spp. was found one in each sample. Therefore, application of sound risk analysis policies is being advocated to provide a scientific base to the host of risk management option which Bangladesh may need to explore to ensure public health and safety.
\end{abstract}

Keywords: street food; contamination; Khulna city; E. coli; Staphylococcus spp.; Klebsiella spp.; Shigella spp.; Salmonella spp.

\section{Introduction}

Street foods are defined as ready-to-eat foods and beverages prepared and/or sold by vendors and hawkers, especially in streets and other similar public places (Bereda et al., 2016). This industry plays an important role in meeting the food requirements of urban dwellers in many cities and towns of developing countries. It feeds millions of people daily with a wide variety of foods that are relatively cheap and easily accessible (Rane, 2011). However, food borne illnesses of microbial origin are a major health problem associated with street foods (Islam et al., 2015). Food contamination with antibiotic resistant bacteria can also be a major threat to public health, since the antibiotic resistance determinants can be transferred to other pathogenic bacteria potentially comprising the treatment of severe bacterial infections (Hasan et al., 2018; Sharma et al., 2015).

The traditional processing methods that are used in preparation, inappropriate holding temperature and poor personal hygiene of food handlers are some of the main causes of contamination of street-vended foods. 
Consumers who depend on such foods are more interested in its convenience and usually pay little attention to its safety, quality and hygiene (Muleta and Ashenafi, 2001). Ready-to-eat street foods are also subjected to cross-contamination from various sources such as utensils, knives, raw foodstuffs, flies that sporadically landing on the foods, vendors bare hand serving and occasional food handling by consumers (Muzaffar et al., 2009; Karmaker et al., 2018). In most cases, tap water is not available for washing hands and utensils at vending sites; hand and utensil washing are usually done in one or more buckets-sometimes without soap. Toilets, waste disposal and refrigeration facilities are rarely available (Hassan et al., 2018). Wastewater and garbage are therefore discarded nearby, providing nutrients for insects and other household rodents, which may carry food borne pathogens (Barro et al., 2006).

Thus, potential health risks are associated with contamination of food by Escherichia coli, Salmonella typhi, Pseudomonas species, Staphylococcus aureus, Proteus species and other species during preparation, postcooking and various handling stages (Tambekar et al., 2008; Schmidt et al., 2003). As a result, food borne illness associated with the consumption of street foods has been reported in several places such as Bangladesh, India (Khairuzzaman et al., 2014), Mexico and Ethiopia. In Bangladesh, health risks associated with street foods are common. Salmonella, Shigella and other food-borne pathogens were identified in similar studies on street-vended foods in this country (Garode and Waghode, 2012).

On the other hand, the prevalence of antimicrobial resistance among food borne pathogens has increased during recent decades (FAO and WHO, 2005; Sarker et al., 2018). A study revealed that $15.18 \%$ of S. aureus stains isolated from street foods were resistant to methicillin. All isolated bacterial colonies were resistant to Penicillin G. The bacterial colonies resistant to methicillin were also resistant to kanamycin, gentamycin, tobramycin and erythromycin (Mamun et al., 2013; Islam et al., 2018). Moreover, the Salmonella species isolated from street foods vended in Khulna were sensitive to most of the drug tested. In a similar study, the isolated Shigella species showed multiple drug resistance patterns against ampicillin, trimethoprim-sulphamethoxazole, chloramphenicol, streptomycin and tetracycline. Since the popularity of street foods is increasing in the towns/cities in particular and in the country in general, this study was intended to assess the microbiological quality and antibiogram status of bacterial isolates from ready- to- eat foods sold by street venders to ensure health status of the consumers.

\section{Materials and Methods}

\subsection{Sample collection}

A total of 20 food samples were randomly chosen and collected from street vendors in the area around Khulna city. These samples were collected in different sealed poly bags to prevent their contact with any other source that can contaminate the samples. Food samples included Chotpoti, Chanachur, Amra and Jolpai. Approximately $200 \mathrm{~g}$ of each food sample was collected using the vendors serving utensils, take parcel and placed into sterile plastic bags. All the collected samples were kept on an icebox during transportation to the laboratory and stored at $4{ }^{\circ} \mathrm{C}$ until testing. They were analyzed within 24 hours of sampling.

\subsection{Preparation of sample}

Adequate amount of different street food (Chotpoti, Chanachur, Amra and Jolpai) samples were uniformly homogenized in mortar and pastel using a sterile diluent as per recommendation of (Balamurugan et al., 2013). A homogenized suspension was made with the help of mortar and pastel. A quantity of 10 gm homogenate sample of each different street was taken aseptically with a sterile spoon and transferred carefully into a sterile pastle containing $90 \mathrm{ml}$ of PBS. Thus 1:10 dilution of the samples was obtained.

\subsection{Enumeration of total viable count (TVC)}

$50 \mu \mathrm{l}$ of each fivefold dilution was transferred and spread onto Plate Count Agar using a micropipette for each dilution for the determination of total bacterial count. The diluted samples were spread as quickly as possible on the surface of the plate. The plates were kept in an incubator at $37^{\circ} \mathrm{C}$ for $24 \mathrm{hrs}$. After incubation, plates exhibiting 30-300 colonies were counted. The average number of colonies in particular dilution was multiplied by the dilution factor to obtain the total viable count. The total viable count was calculated according to ISO (1995). The results of the total bacterial count were expressed as the number of colony forming units (CFU) per $\mathrm{ml}$ of food samples.

\subsection{Isolation of associated bacteria}

Bacteriological examination was carried out using standard method for aerobic bacteria (Brown, 2005). Each sample of Chotpoti, Chanachur, Amra and Jolpai samples were inoculated separately in nutrient broth (NB) to 
promote growth of bacteria. Each group of these media were incubated at $37^{\circ} \mathrm{C}$ for overnight. The colonies on primary cultures were repeatedly subcultured by streak plate method (Cheesbrough, 1985) until the pure culture with homogenous colonies were obtained. Media such as Nutient agar, MacConkey agar, Eosin Methylene Blue agar, Salmonella Shigella (SS) agar, and Manitol Salt Agar (MSA) were used for sub-cultures and incubated at $37^{\circ} \mathrm{C}$ for 24 hours for growth.

\subsection{Identification of associated bacteria}

The cultural examination of street food (Chotpoti, Chanachur, Amra and Jolpai) samples for bacteriological study was done according to the standard method International Commission on Microbiological Specifications for Foods (ICMSF, 1985). Identification of bacteria was performed on the basis of colony morphology Gram's staining reaction and biochemical test. Biochemical tests, such as sugar fermentation, coagulase, catalase, MR, VP, and indole tests, were performed as per the standard methods (Cheesbrough, 1985).

\section{Results and Discussion}

\subsection{Results of microbial load by total viable count (TVC)}

The (TVC) of different street food (Jolpai, Chotpoti, Chanachur and Amra) samples collected from different vendors are shown in Table 1. The highest numbers of bacterial colonies were observed in Jolpai sample $\left(6.7^{*} 10^{7} \mathrm{CFU} / \mathrm{g}\right)$ followed by Chotpoti sample $\left(6.3 \times 10^{7} \mathrm{CFU} / \mathrm{g}\right)$, Chanachur sample $\left(6.1 \times 10^{7} \mathrm{CFU} / \mathrm{g}\right)$ and Amra sample $\left(5.9 \times 10^{7} \mathrm{CFU} / \mathrm{g}\right)$.

Table 1. Microbial load by total viable count (TVC).

\begin{tabular}{llll}
\hline Type of food & Dilution & Number of colony & Total viable count (TVC) \\
\hline & $10^{-3}$ & 96 & $9.6 \times 10^{5} \mathrm{CFU} / \mathrm{g}$ \\
Chotpoti & $10^{-4}$ & 71 & $7.1 \times 10^{6} \mathrm{CFU/g}$ \\
& $10^{-5}$ & 64 & $6.4 \times 10^{7} \mathrm{CFU} / \mathrm{g}$ \\
& $10^{-1}$ & Over 300 & TNTC \\
& $10^{-2}$ & Over 300 & TNTC \\
& $10^{-1}$ & Over 300 & TNTC \\
Chanachur & $10^{-2}$ & Over 300 & TNTC \\
& $10^{-3}$ & 84 & $8.4 \times 10^{5} \mathrm{CFU} / \mathrm{g}$ \\
& $10^{-4}$ & 74 & $7.4 \times 10^{6} \mathrm{CFU} / \mathrm{g}$ \\
Amra (Spondias mombin) & $10^{-5}$ & 60 & $6.0 \times 10^{7} \mathrm{CFU} / \mathrm{g}$ \\
& $10^{-1}$ & Over 300 & TNTC \\
& $10^{-2}$ & Over 300 & TNTC \\
& $10^{-3}$ & 80 & $8.0 \times 10^{5} \mathrm{CFU} / \mathrm{g}$ \\
& $10^{-4}$ & 67 & $6.7 \times 10^{6} \mathrm{CFU} / \mathrm{g}$ \\
Jolpai (Ceylon Olive) & $10^{-5}$ & 59 & $5.9 \times 10^{7} \mathrm{CFU} / \mathrm{g}$ \\
& $10^{-1}$ & Over 300 & TNTC \\
& $10^{-2}$ & Over 300 & $9.1 \times 10^{5} \mathrm{CFU} / \mathrm{g}$ \\
& $10^{-3}$ & 91 & $7.6 \times 10^{6} \mathrm{CFU} / \mathrm{g}$ \\
\hline
\end{tabular}

\subsection{Results of bacteriological investigation}

A total of 20 different street food (Jolpai, Chotpoti, Chanachur and Amra) samples were collected from different places in Khulna for this study. Among 20 different street food (Jolpai, Chotpoti, Chanachur and Amra) samples, Shigella spp., Staphylococcus spp., Klebsiella spp., Salmonella spp. and Escherichia coli were found.

\subsection{Results of isolation of bacteria from street vended food}

Five genera of bacteria such as Shigella spp., Staphylococcus spp., Klebsiella spp., Salmonella and Escherichia coli were isolated from different street food (Jolpai, Chotpoti, Chanachur and Amra) samples. During the study period a total 20 samples were collected from different street food. In case of Jolpai 3(50\%) positive for Escherichia coli, 1(16.66\%) positive for Staphylococcus spp., 1(16.66\%) positive for Klebsiella spp. and 1(16.66\%) were positive for Shigella spp. In case of Chanachur 2(50\%) positive for Staphylococcus spp., 1(25\%) positive for Escherichia coli and 1(25\%) were positive for Klebsiella spp. In case of Chotpoti 2(40\%) positive for Staphylococcus spp. and Klebsiella spp. and 1(20\%) were positive for Escherichia coli. In case of Amra 2(40\%) positive for Escherichia coli, 1(20\%) positive for Staphylococcus spp. and 1(20\%) were positive 
for Klebsiella spp. respectively. In 20 street food samples Escherichia coli were found highest 3(50\%) Jolpai samples and 2(40\%) Amra samples, then another organisms Staphylococcus spp. was found highest 2(50\%) Chanachur and 2(40\%) Chotpoti samples and then Klebsiella spp. was found highest 2 (40\%) Chotpoti samples which were shown in Table 2.

Table 2. Results of isolation of bacteria from street vended food.

\begin{tabular}{lllllll}
\hline \multirow{2}{*}{ Bacterial isolate } & \multicolumn{3}{c}{ Types of sample } & \multirow{2}{*}{ Percentage (\%) } \\
\cline { 2 - 6 } & Jolpai & Chanachur & Chotpoti & Amra & Total & $40 \%$ \\
\hline E. coli & $3(50 \%)$ & $2(50 \%)$ & $1(20 \%)$ & $2(40 \%)$ & 8 & $25 \%$ \\
Staphylococcus spp. & $1(16.66 \%)$ & $1(25 \%)$ & $2(40 \%)$ & $1(20 \%)$ & 5 & $20 \%$ \\
Klebsiella spp. & $1(16.66 \%)$ & $1(25 \%)$ & $1(20 \%)$ & $1(20 \%)$ & 4 & $10 \%$ \\
Shigella spp. & $1(16.66 \%)$ & $0(0 \%)$ & $1(20 \%)$ & $0(0 \%)$ & 2 & $5 \%$ \\
Salmonella spp. & $0(0 \%)$ & $0(0 \%)$ & $0(0 \%)$ & $1(20 \%)$ & 1 & $\mathbf{1 0 0 \%}$ \\
Total bacteria identified & $\mathbf{6}$ & $\mathbf{4}$ & $\mathbf{5}$ & $\mathbf{5}$ & $\mathbf{2 0}$ & \\
\hline
\end{tabular}

\subsection{Results of isolation of bacteria}

Cultural characteristics of each type of bacteria isolated from different street food were studied for the determination of size, shape and colony characteristics in various bacteriological media. The staining property of primary culture of each of the different street food samples indicated the presence of more than one type of bacteria in the same smear. The pure cultures of the organism from each mixed culture were obtained by repeated streak plate method using different simple and selective solid media for study. The cultural characteristics of Klebsiella spp., Staphylococcus spp., Shigella spp., Salmonella spp. and E. coli exhibited on the media are presented in Table 3.

Table 3. Cultural characteristics of the bacterial isolates of different street food.

\begin{tabular}{lll}
\hline Suspected case of bacteria & Name of media & Cultural characteristics \\
\hline Klebsiella spp. & MacConkey agar & Large, mucoid, bright pink lactose fermented colony \\
Staphylococcus spp. & MS agar & Medium yellowish colony \\
Shigella spp. & SS Agar & Small non-lactose fermented colony \\
Salmonella spp. & SS Agar & Small non-lactose fermented with black center colony \\
Escherichia coli & EMB agar, & Metallic sheen (greenish black) - colony \\
\hline
\end{tabular}

Notes: MS Mannitol salt, EMB = Eosin methylene blue, SS=Salmonella Shigella

\subsection{Results of staining characteristics of the isolated bacteria}

The staining characteristics of the isolated organisms were determined according to Gram's staining technique. Morphological and staining characteristics of bacteria recorded from Jolpai, Chotpoti, Chanachur and Amra samples by Gram's staining are presented in Table 4.

Table 4. Morphological and staining properties of the bacterial isolates by Gram's staining.

\begin{tabular}{|c|c|c|c|}
\hline \multicolumn{3}{|c|}{ Staining characteristics } & \multirow{2}{*}{ Remarks } \\
\hline Shape & Arrangement & Gram's staining character & \\
\hline Rod in shape & Single, pairs or cluster & $(-) \mathrm{ve}$ & Klebsiella spp. \\
\hline Cocci in shape & Arranged in grapes like cluster & $(+) \mathrm{ve}$ & Staphylococcus spp. \\
\hline Rod in shape & Single or pair & $(-)$ ve & Shigella spp. \\
\hline Rod in shape & Single or pair & $(-)$ ve & Salmonella spp. \\
\hline Short plump rods & Single, paired or in short chain & $(-)$ ve & E. coli \\
\hline
\end{tabular}

Notes: (+)Ve = Positive; (-) Ve= Negative

\subsection{Results of biochemical tests of different isolates}

Isolated E. coli, Salmonella spp., Staphylococcus spp. were positive and Klebsiella spp. was negative for methyl red test. All isolates were positive for catalase test with gas bubble formation. All isolates were negative for oxidase test with no colour change except Staphylococcus spp. E. coli, Staphylococcus spp. were negative and Salmonella spp. and Klebsiella spp. were positive for voges-proskauer test. 


\section{Conclusions}

In general, this study demonstrated that street vended foods which are sold on the streets of studied areas were considerably contaminated. The foodborne bacteria and antibiotic resistance isolates detected in this study are also evident that street foods might pose a major problem for public health. Lack of training (orientation) on the proper handling and processing of food, poor personal hygiene of venders and unhygienic surroundings could be possible factors for observed problems in that locality. Therefore, education for vendors on food safety and hygienic practices is essential to reduce contamination rate. In addition, regular inspection on food vending practices and safety of street foods is required to improve the health standards of consumers.

\section{Conflict of interest}

None to declare.

\section{References}

Ali M, MR Khan and ML Saha, 2011. Antibiotic resistant patterns of bacterial isolates from ready-to-eat (RTE) street vended fresh vegetables and fruits in Dhaka City. Bangladesh J. Sci. Res., 24: 127-134.

Barro N, AR Bello, Y Itsiembou, A Savadogo, CAT Owattara, P Nikiema, De SC and AS Traore, 2007. Street vended foods Improvement: Contamination Mechanism and Application of food safety objective strategy: Critical Review. Pakistan J. Nutr., 6:1-10.

Barro N, AR Bello, S Aly, CAT Ouattara, AJ IIboudo and AS Traore, 2006. Hygienic status and assessment of dishwashing waters, utensils, hands, and pieces of money from street food processing sites in Ouagadougou (Burkina Faso). Afr. J. Biotechnol., 5: 1107-1112.

Bereda T, Y Emerie, M Reta and H Asfaw, 2016. Microbiological Safety of Street Vended Foods in Jigjiga City, Eastern Ethiopia. Ethiop J. Health Sci., 26: 161.

Bhowmik, 2010. Street Vendors in the Global Urban Economy, Routledge: Taylor \& Francis, New Delhi, India.

Bryan FL, SC Michanie, P Alvarez and A Paniagua, 1988. Critical control points of street vended foods in the Dominican Republic. J. Food Prot., 51: 373-383.

Buxton A and G Fraser, 1977. Animal Microbiology. Vol. 1. Blackwell Scientific Publications, Oxford, London, Edinburg, Melbourne. 15: 177-183.

Cappuccino $\mathrm{N}$ and D Carpenter, 2005. Invasive exotic plants suffer less herbivory than non-invasive exotic plants. Biol. Lett., 1: 435-438.

Cheesbrough M, 1985. Medical laboratory manual for tropical countries. Ist edition. Microbiology. English Language Book Society, London. pp. 400-480.

Das M, CC Rath and UB Mohapatra, 2011. Bacteriology of a most popular street food (Panipuri) and inhibitory effect of essential oils on bacterial growth. J. Food Sci. Technol., 49: 564-571.

Dawson RJ and C Canet, 1991. International activities in street foods. J. Food Control, 2: 135-139.

FAO and WHO, 2005. Informal food distribution sector in Africa (street foods): Importance and challenges. Proceedings of the FAO/WHO Regional Conference on Food Safety for Africa, October 3-6, 2005, Harare, Zimbabwe.

FAO, 2007. The informal food sector" http://www.informalfood.unibo.it 2007-11-23

Garode AM and SM Waghode, 2012. Bacteriological status of street-vended foods and public health significance: A case study of Buldana District, MS, India. ISCA J. Biol. Sci., 1: 69-71.

Hasan M, SML Kabir, T Rahman and YA Sarker, 2018. Bacteriological quality assessment of buffalo meat collected from different districts of Bangladesh with particular emphasis on the molecular detection and antimicrobial resistance of the isolated Salmonella species. Asian Australas. J. Food Saf. Secur., 2: 12-20.

Hassan MS, SML Kabir, YA Sarker and T Rahman, 2018. Bacteriological assessment of tap water collected from different markets of Mymensingh, Gazipur and Sherpur districts of Bangladesh with special focus on the molecular detection and antimicrobial resistance of the isolated Escherichia coli. Asian Australas J. Food Saf. Secur., 2: 21-28.

Islam K, SML Kabir, AKMZ Haque, YA Sarker and Sikder MH, 2018. Molecular detection and characterization of Escherichia coli, Salmonella spp. and Campylobacter spp. isolated from broiler meat in Jamalpur, Tangail, Netrokona and Kishoreganj districts of Bangladesh. African J. Microbiol. Res., 12: 761770.

Islam S, N Nasrin, F Rizwan, L Nahar, A Bhowmik, SA Esha, KA Talukder, M Akter, A Roy and M Ahmed, 2015. Microbial contamination of street vended foods from a university campus in Bangladesh. Southeast Asian J. Trop. Med. Public Health, 46: 480-485.

Karmaker S, SML Kabir, AKMZ Haque, M Ferdousur, R Khan and YA Sarker, 2018. Screening of human 
diarrhoeal samples in Mymensingh city of Bangladesh for the isolation, identification and antimicrobial resistance profiles of Campylobacter spp. African J. Microbiol. Res., 12: 771-778.

Khairuzzaman M, FM Chowdhury, S Zaman, AA Mamun and ML Bari, 2014. Food safety challenges towards safe, healthy and nutritious street foods in Bangladesh. Int. J. Food Sci., Article ID 483519, 9 pages.

Latham MC, 1997. Human nutrition in tropical Africa. FAO, Rome. pp. 329-437.

Lues JFR, MR Rasephei, P Venter and MM Theron, 2006. Assessing food safety and associated food handling practices in street food vending. Int. J. Environ. Health Res., 16: 319-328.

Mamun MA, MM Rahman and TC Turin, 2013. Microbiological quality of selected street food items vended by school based street food vendors in Dhaka, Bangladesh. Int. J. Food Microbiol., 166: 413-418.

Merchant LA and RA Packer, 1967.Veterinary Bacteriology and Virology. Seventhedi. The Iowa University Press, Ames, Iowa USA. 286-306.

Moy G, A Hazzard and F Kiiferstein, 1997. Improving the safety of street-vended food. World Health Status, 50: $124-131$.

Muleta D and M Ashenafi, 2001. Bacteriological profile and holding temperatures of street-vended foods from Addis Ababa. Int. J. Environ. Health Res., 1: 95105.

Muzaffar AT, I Huq and BA Moreik, 2009. Entrepreneurs of the streets: An analytical work on the street food vendors of Dhaka city. Int. J. Busi. Manag., 4: 80-88.

Olaitan JO, OB Shittu and AA Akinliba, 2011. Antibiotic resistance of enteric bacteria isolated from duck droppings. J. Appl. Biosci., 45: 3008-3018.

Rane S, 2011. Street Vended Food in Developing World: Hazard Analyses. Indian J. Microbiol., 51: 100-106.

Rath CC and S Patra, 2012. Bacteriological quality assessment of selected street foods and antibacterial action of essential oils against food-borne pathogens. Int. J. Food Safety, 14: 5-10.

Sarker YA, MM Hasan, TK Paul, SZ Rashid, MN Alam and MH Sikder, 2018. Screening of antibiotic residues in chicken meat in Bangladesh by thin layer chromatography. J. Adv. Vet. Anim. Res., 5: 140-145.

Schmidt R, MG Ren'ee, L Douglas, Archer and RS Keith, 2003. General overview of the causative agents of food-borne illness. This document is FSHNO33, one of a series of the Food Science and Human Nutrition Department, Florida Cooperative Extension Service, WAS, University of Florida.

Sharma A, H Bhardwaj and I Ravi, 2015. Microbiological analysis of street vended food in West Delhi. Indian J. Appl. Res., 5: 291-294.

Sheth M, R Gurudasani and R Mudbidri, 2005. Identification of hazards in street foods of Vadodara, India. J. Nutr. Diet., 42: 266-274.

Sivapalasingam S, CR Friedman, L Cohen and RV Tauxe, 2004. Fresh produce a growing cause of outbreaks of food-borne illness in the United States, 1973 through 1997. J. Food Prot., 67: 2342-2353.

Tambekar D, H Kulkarni, RVSD Shirsat and DG Bhadange, 2011. Bacteriological quality of street vended food Panipuri. A case study of Amravati city (ms) India. Biosci. discov., 2: 350-354.

Tambekar DH, VJ Jaiswal, DV Dhanorkar, PB Gulhane and MN Dudhane, 2008. Identification of microbiological hazards and safety of ready-to-eat food vended in streets of Amravati city, India. J. Appl. Biosci., 7: 195-201.

Tsang D, 2002. Microbiological guidelines for ready to eat food. Road and Environmental Hygiene Department, Hong Kong, 115-116. 